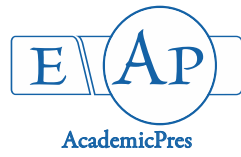

\title{
Axillary Shoots Derived from Thin Cell Layer and Adenine Sulphate Application in in vitro Mass Propagation of Gerbera [Gerbera jamesonii (H. Bolus ex Bolus f.)]
}

\author{
Budi WINARTO ${ }^{1 *}$, Kurnia YUNIARTO², Dan Mega WEGADARA ${ }^{3}$ \\ ${ }^{1}$ Central Java Assessment Institute for Agriculture Technology \\ Jl. Soekarno Hatta KM.26 No.10, Kotak Pos 124, Tegalsari, Bergas Lor, Bergas, Semarang, 50552 Central Java, \\ Indonesia; budi.winarto67@yahoo.co.id (*corresponding author) \\ ${ }^{2}$ Cipanas Ornamental Garden, Jl. Landbouw, Cipanas-Cianjur Cianjur 43253, Jawa Barat-Indonesia; kurnia_yuniarto@yahoo.co.id \\ ${ }^{3}$ Indonesian Ornamental Crops Research Institute, Jln. Raya Ciherang, PO. Box 8, Sindanglaya, Pacet-Cianjur 43253, \\ Jawa Barat-Indonesia; mwegadara@gmail.com
}

\begin{abstract}
A new route of in vitro mass propagation protocol of Gerbera jamesonii (H. Bolus ex Bolus f.) derived from application of thin cell layers (TCL) and adenine sulphate (AS) was successfully developed and established. Shoot tip explants and halfstrength MS medium containing $0.25 \mathrm{mg} / \mathrm{l}$ N6-benzylaminopurine (BAP), $20 \mathrm{~g} / \mathrm{l}$ sucrose and $7 \mathrm{~g} / \mathrm{l}$ Swallow agar were used as explant source and basic medium. Different TCL of transversal TCL (tTCL) and longitudinal TCL (ITCL) in four slicing positions of 1, 2, 3 and 4; varieties and clones i.e. G. jamesonii 'Black Jack', 'Carambole', 'Nuance', 'Violente', 01.098 and 11.46 clone; AS concentrations viz. 0, 20, 40, 60, 80 and $100 \mathrm{mg} / \mathrm{l}$ were tested in the study. Each step of in vitro culture established had unique and specific results. In the initiation stage, first slicing position of 'Black Jack' shoot tip tTCL was the most optimal combination treatment to produce 7.0 shoots per explant with 13.5 leaves. The first slicing position on shoot tip explants of 01.098 clone tTCL and $20 \mathrm{mg} / \mathrm{l}$ AS in half-strength MS medium containing $0.25 \mathrm{mg} / \mathrm{l}$ BAP were the most optimal combination treatment in obtaining the highest number of shoots produced per shoot up to 9.4 shoots per shoot with 34.1 leaves and $2.37 \mathrm{~cm}$ length of leaves in the proliferation stage, however the treatment did not give significant effect compared to control. Under periodical subcultures on the basic medium, number of shoots and leaves increased gradually from the initial culture with 3-6 shoots per shoot and 9.4-11.6 leaves till the fourth subculture with 6-11 shoots per shoot and 16.7-28.8 leaves and declined thereafter. Subculturing of shoots in accordance to produce qualified shoots for planting materials could be carried out till sixth to seventh subculture. The highest shoot multiplication rate (SMR) was established on 01.098 clone with as high as 7.3. The well shoots were easily rooted on half-strength MS medium supplemented with $0.1 \mathrm{mg} / \mathrm{l} \mathrm{BAP}, 0.05 \mathrm{mg} / \mathrm{l}$ NAA and $1.5 \mathrm{~g} / \mathrm{l}$ AC. Plantlets were then transferred to ex vitro condition for acclimatization on a mixture of burned-rice husk and organic manure $(1: 1, \mathrm{v} / \mathrm{v})$ with $85-100 \%$ survivability. The 'Black Jack' and 11.46 clone were the best genotypes on the acclimatization stage with $100 \%$ survivability of plantlets. Results of the study have implication that first slicing position of shoot tip tTCL can be applied in establishing of in vitro propagation protocol for other gerberas.
\end{abstract}

Keywords: adenine sulfate; Gerbera jamesonii; in vitro culture stages; thin cell layer (TCL)

\section{Introduction}

Gerbera [Gerbera jamesonii (H. Bolus ex Bolus f.)] is one of important flower commodities both in local and international market. The commodity has high economical value, either as cut flower or potted plants; has varied in calor and shape, interesting and attractive (Tyagi and Kothari, 2004; Naz et al., 2012). The flower has long vase life, resistance to transportation damage and no riskiness in obtaining a good market price (Chung et al., 2016). Recently, the gerbera cut flowers in Dutch Auction were positioned in the fourth important cut flowers after spray
Chrysanthemum (CBI, 2016), while in the Indonesian market, the cut flower accupied in the fourth position after Carnation (Statistic Indonesia, 2017b). The Gerbera is widely cultivated commercially at Bogor, Cianjur and Lembang-West Java; Bandungan and TawangmanguCentral Java; Pasuruan and Batu-East Java; Tabanan-Bali; Tomohon-North Sulawesi; etc. Total cultivation areas of the flower were 183.7 ha with 5.4 million stems of total production and 29.5 stems productivity per $\mathrm{m}^{2}$ on 2016 (Statistic Indonesia, 2017abc). In Indonesian market, the cut flowers depending on variety and quality were sold 9,000 to 25,000 rupiahs per bunch (Umkm-news, 2016; Ilham-florist, 2017). Though market demand and 
64

cultivation areas of the flower increase significantly in each year, development of the gerbera in commercial scales is frequently limited by availability of qualified-planting materials sustainability.

Traditionally, the gerbera can be propagated vegetativelly using rhizome divisions and cuttings and generativelly using seeds (Kanwar and Kumar, 2008). Though the vegetative propagation using the rhizome divisions and cutting can maintain uniformity and genetic purity, the method is laborious and time consuming with limited-results, while the generative method utilizing seeds, though produce high number of regenerants, the technique results in varied-planting materials genetically and phenotipically (Rukmana, 1995; Cardoso and Teixeira da Silva, 2013). Due to those limitaions, the both methods can not be used in developing the flower in commercial purposes, therefore production of high qualified-planting materials continually via tissue culture works was importantly addressed. Utilization of the method expected can prepare a large number of planting materials which are uniform, vigorous and pathogen free in a shorter time (Mohamed and Ozzambak, 2014).

Several in vitro mass propagation protocols on gerbera using axillary and adventitious shoot proliferation method have been published previously. The method generally used leaves, petals, capitulars and shoot tips as explant souces; Murashige and Skoog (1962, MS) medium utilized as basic medium; varied hormone concentrations and combinations of Thidiazuron (TDZ; 0.75-1.5 mg/l), N6benzylaminopurine /benzyladenine (BAP/BA; $1-10 \mathrm{mg} / \mathrm{l}$ ), Kinetin (Kin; 1-4 mg/l), 2,4-dichlorophenoxy acetic acid (2,4-D; 0.5-3.0 mg/l), $\alpha$-naphthalene acetic acid (NAA; 0.5$1.0 \mathrm{mg} / \mathrm{l}$ ), indole-3-acetic acid (IAA; 0.1-1.0 mg/l), Picloram (Pic; 0.01-0.02 mg/l) (Tyagi and Kothari, 2004; Kumar and Kumar, 2006; Shabbir et al., 2012; Naz et al., 2015; Winarto and Yufdy, 2017). Furthermore application of those variations successful regenerated shoots from 4 - 10 shoots per explant and explants were generally cultured in higher sizes, however application of thin cell layers (TCL) and adenine sulphate (AS) in in vitro mass propagation of gerbera is still few.

TCL is a small piece of excised explant from different plant organs (stems, leaves, floral inflorescences, flower primordia or floral organs, cotyledons, hypo-/epicotyls, apical zones or embryos), either longitudinally (lTCL) or transversally (tTCL). The lTCLs usually contain only one tissue type, such as a monolayer of epidermal cells, whereas tTCLs include a small number of cells from different tissue types involving epidermal, cortical, cambium, perivascular and medullar tissue, parenchyma cells (Tran Thanh Van, 1980; Teixeira da Silva, 2003ab, 2004; Teixeira da Silva et al., 2006). 1TCLs and tTCLs generally have $5-10 \mathrm{~mm}$ in length and diameter and maximum $1 \mathrm{~mm}$ in thickness (Teixeira da Silva, 2008). For in vitro mass propagation purposes of plants, the TCL was successfully applied on Begonia (Nhut et al., 2005a and 2010), Gerbera (Nhut et al., 2007), Cymbidium (Vyas et al., 2010),Dendrobium candidum (Zhao et al., 2012), dan Rosa damascene (Kshirsagar and Braganza, 2012). However application TCL for in vitro mass propagation of gerbera especially in Indonesia was not reported yet.
Adenine (adenine sulphate form (AS) for in vitro culture purpose) is a cytokinin analogue affecting many aspects of plant development such as stimullating somatic embryogenesis and caulogenesis as well as promoting adventitious and axillary shoot formation (Van Staden et al., 2008; Bantawa et al., 2009; Wróblewska, 2012). It also had positive effect on root formation (Mathur et al., 2008). In in vitro plant culture, the AS was successfully applied to induce and form shoots on Phaseolus vulgaris (Arias et al., 2012), Begonia $\times$ hiemalis (Awal et al., 2013); Thevetia peruviana (Zibbu and Batra, 2010); to multiply shoots of Carica papaya (Saha et al., 2004; Schmildt et al., 2007), Picrorbiza scrophulariiflora (Bantawa et al., 2009) and to induce roots on Fuchsia hybrida (Wróblewska, 2012). While application of adenine sulphate for axillary proliferation in in vitro mass propagation of gerbera was not reported yet.

Reliable and new route of in vitro mass propagation protocol of Gerbera initially by application of TCL followed by utilization of AS for shoot multiplication, plantlet preparation to its acclimatization was successfully developed and established. Each treatment in each stage resulted interesting findings and discussed detail in the paper.

\section{Materials and Methods}

\section{Planting material and itspreparation}

Material used in this study was G. jamesonii 'Black Jack', 'Carambole', 'Nuance', 'Violente', 01.098 and 11.46 clones. The 'Black Jack', 'Carambole', 'Nuance' and 'Violente' was commercial varieties that were widely cultivated by farmer at Ciwalen, Pacet-Cianjur, West Java-Indonesia. While 01.098 and 11.46 clones of gerbera were selected clones derived from breeding program of Indonesian Ornamental Crops Research Institute (IOCRI) breeder ready to be commercialized to farmers and growers. The clones were cultivated in screen house of Cipanas Experimental Garden (CEG) of IOCRI. Shoots with 1-2 young leaves were harvested from the donor plants at farmer's location and CEG screen house in 07.00-09.00 am. The shoots were then brougth to tissue culture laboratory of IOCRI for sterilization purpose.

\section{Explant sterilization and preparation}

Before explant sterilization, all shoots were prepared by removing all leaves, reducing their petiole length and leaving their basal parts. Furthermore, all explants with short basal parts of petioles were pre-treated by placing them under running tap water for 60 minutes ( $\mathrm{min}$ ), followed by immersing them in $1 \%$ soap solution with manual shaking for $30 \mathrm{~min}$, pesticide solution (50\% benomil and $20 \%$ kanamycin sulphate) for 30 min and rinsing 4-5 times (@3 min each) using distilled water to remove all remain disinfection materials. The explants were then moved to laminar air flow cabinet for sterilization. They were soaked in $0.05 \%$ mercury chloride $\left(\mathrm{HgCl}_{2}\right)$ solution added by 5 drops of Tween 20 for $5 \mathrm{~min}$, followed by rinsing with sterile distilled water (SDW) 4-6 times (@3 min each).

The shoot tips as explant sources were prepared by removing all basal parts of left-leaf petioles, one by one, 
using pinset carefully till grow point of apical dome easily observed. After each petiole basal part successfully removed, ommiting smooth hairs were carried out gently using small pinset under binoculer microscope under 40 times magnification. After all basal parts of petioles removed, the shoot tip was sliced vertically in four position $( \pm 1.5 \mathrm{~mm}$ in length and width) then sectioned transversally $\pm 3 \mathrm{~mm}$ in length from the tip point. The isolated-shoot tips were further sterilized with $0.01 \% \mathrm{HgCl}_{2}$ for $3 \mathrm{~min}$ and then rinsing with SDW as previuos described. The shoot tips were shortened by slicing transversally and longitudinally till the final size of the shoot tip was $1 \times 1-1.5 \times 2.5 \mathrm{~mm}$ in length (l), width (w) and height (h). The shoot tips were then cultured vertically on enlargement medium.

\section{Shoot tip enlargement}

Preparing shoot tips for TCL explant sources was carried out by culturing small shoot tips on half-strength MS medium containing $1.5 \mathrm{mg} / \mathrm{l} \mathrm{TDZ}$ and $0.25 \mathrm{mg} / \mathrm{l} \mathrm{BAP}$ for 1.5 months in dark condition. After dark incubation, the shoot tip cultures were transferred to light incubation with $12 \mathrm{~h}$ photoperiod under cool fluorescent lamps of 13 $\mu \mathrm{mol} / \mathrm{m}^{2} / \mathrm{s}$ light intensity for 15 days. In the end of culture, size of shoot tips enlarged in size up to $2.2 \times 3.5 \times 5.0 \mathrm{~mm}$ ( 1 $\times \mathrm{w} \times \mathrm{h}$ ). The enlarged-explants were then used as explant sources for TCL.

\section{Culture incubation}

Culture incubation applied in the study was dark and light incubation. Dark incubation was carried out by placing explant cultures in cartoon box, then placed the cartoon box in rack covered by black cloth. While light incubation was performed by placing explant cultures under cool fluorescent lamps for $12 \mathrm{~h}$ photoperiod with $~ 13$ $\mu \mathrm{mol} / \mathrm{m}^{2} / \mathrm{s}$ light intensity.

\section{Effect of TCL types and slicingposition on shoot initiation}

TCL types tested in the step were transversal TCL (tTCL) and longitudinal TCL (ITCL). In the experiment, enlarged-shoot tip explants were sliced from top to bottom position with less than $1 \mathrm{~mm}$ in thickness for $\mathrm{tTCL}$ and from left to right position with the similar thickness. Only four positions were used in the study both for tTCL and ITCL. For tTCL, the explant positions were counted from top to bottom part as 1,2,3 and 4 slicing positions. While for ITCL, the explant positions were calculated from left to right part as 1, 2, 3 and 4 slicing positions. All explants for the experiment were derived from G. jamesonii 'Black Jack' as plant model. The explants which were separated based on slicing position were then cultured on half-strength MS medium supplemented with $0.25 \mathrm{mg} / \mathrm{l} \mathrm{BAP}, 20 \mathrm{~g} / \mathrm{l}$ sucrose, $7 \mathrm{~g} / \mathrm{l}$ Swallow agar and $5.8 \mathrm{pH}$ of media. The media were prepared in $9 \mathrm{~cm}$ petridishes and sterilized the media in all American autoclave under $121^{\circ} \mathrm{C}$ and $15 \mathrm{kPa}$ for 20 minutes. The factorial experiment was arranged in randomized completely block design (RCBD) with 3 replications. Each treatment consisted of three petridishes. Each petridish was cultured 5 explants.

\section{Effect of $t T C L$ slicing positions and respon of varieties on shoot initiation}

The tTCL slicing positions tested in the experiment were 1, 2, 3 and 4 that were counted from the top to bottom part as describe previously. The ITCL was not used anymore due to lower results for shoot initiation compared to the tTCL. Varieties and clones explored in the study were G. jamesonii 'Black Jack', 'Carambole', 'Nuance' dan 'Violente'. The explants which were separated based on slicing position were then cultured on half-strength MS medium supplemented with $0.25 \mathrm{mg} / \mathrm{BAP}, 20 \mathrm{~g} / \mathrm{l}$ sucrose, $7 \mathrm{~g} / \mathrm{l} \mathrm{Swallow}$ agar and $5.8 \mathrm{pH}$ of media. The media were prepared and sterilized as described previously. The factorial experiment was arranged in RCBD with 3 replications. Each treatment consisted of three petridishes. Each petridish was cultured 5 explants.

Effect of adenine sulphate consentrations and respon of varieties on shoot initiation

The AS concentrations tested in the experiment were 0 , 20, 40, 60, 80 and $100 \mathrm{mg} / \mathrm{l}$. The different concentrations of AS were added in the half-strength MS medium augmented with $0.25 \mathrm{mg} / \mathrm{l}$ BAP, $20 \mathrm{~g} / \mathrm{l}$ sucrose, $7 \mathrm{~g} /$ Swallow agar and $5.8 \mathrm{pH}$ of media. While response of varieties investigated in the stage were $G$. jamesonii 'Black Jack', 'Carambole', 'Nuance' and'Violente'. Explants used in the experiment were the first slicing position of shoot tips as the best position for high shoot initiation established in the previous experiments. The media were prepared and sterilized as described previously. The factorial experiment was arranged in RCBD with 3 replications. Each treatment consisted of three petridishes. Each petridish was cultured 5 explants

Effect of adenine sulphate consentrations and respon of varieties and clones on shoot multiplication

The AS concentrations tested in the experiment were 0 , 20, 40, 60, 80 and $100 \mathrm{mg} / \mathrm{l}$. The different concentrations of AS were added in the half-strength MS medium augmented with $0.25 \mathrm{mg} / \mathrm{l} \mathrm{BAP}, 20 \mathrm{~g} / \mathrm{l}$ sucrose, $7 \mathrm{~g} / \mathrm{l}$ Swallow agar and $5.8 \mathrm{pH}$ of media. While response of varieties and clones investigated in the stage were $G$. jamesonii 'Black Jack', 'Carambole', 'Nuance', 01.098 and 11.46 clones. Explants used in the experiment were the first slicing position of shoot tips. The media were prepared and sterilized as described previously. The factorial experiment was arranged in RCBD with 3 replications. Each treatment consisted of three botlles. Each bottle was cultured 5 shoots. In the stage, bottles used were jam bottles with $7 \mathrm{~cm}$ in diameter and $13 \mathrm{~cm}$ in height and $30 \mathrm{ml}$ of semi-solid media.

Response of varieties and clones on shoot multiplication rate

Response of varieties and clones utilized in the stage were G. jamesonii 'Black Jack', 'Carambole', 'Nuance', 01.098 and 11.46 clones. Regenerated shoots derived from each subculture period were subcultured periodically on half-strength MS medium augmented with $0.25 \mathrm{mg} / \mathrm{l} \mathrm{BAP}$ every 1.5 months till the highest number of shoots produced were determined then reduced number of shoots recorded thereafter. Multiplication rate of shoots was calculated by counting number of shoots in the end of culture derived from one shoot cultured in the initial culture. The experiment was arranged in completely randomized design (CRD) with 5 replications. Each treatment was consisted of 3 bottles and each bottle contained 5 shoots. 
66

Effect of rooting media and response of varieties and clones on root formation

In the plantlet preparation, rooting media tested in the stage were half-strength MS medium supplemented with $0.1 \mathrm{mg} / \mathrm{l} \mathrm{BAP}$ and $0.5 \mathrm{mg} / \mathrm{l} \mathrm{NAA}$ without activated charcoal (AC) application and half-strength MS medium containing $0.1 \mathrm{mg} / \mathrm{l} \mathrm{BAP}, 0.5 \mathrm{mg} / \mathrm{l} \mathrm{NAA}$ dan $1.5 \mathrm{~g} / \mathrm{l} \mathrm{AC}$. While varieties and clones utilized in the study were $G$. jamesonii 'Black Jack', 'Carambole', 'Nuance', 01.098 and 11.46 clones. The factorial experiment was arranged in CRD with 5 replications. Each treatment was consisted of 3 bottles and each bottle contained 5 shoots.

\section{Response of varieties and clones on their plantlet acclimatization}

In the final stage, response of three varieties and two clones on thier plantlet acclimatization was tested. The $G$. jamesonii investigated in the experiment were 'Black Jack', 'Carambole', 'Nuance', 01.098 and 11.46 clones. In the acclimatization, plantlets with 4-9 leaves and 2-6 roots ready for acclimatization successfully prepared were picked them up from the culture vessel using blunt pinset carefully. Root part of each plantlet was cleaned from remaining agar roots attached under tap water (Fig. 7l). The root plantlets were then soaked in $1 \%$ pesticide solution of $50 \%$ benomyl and $20 \%$ streptomycin sulphate for three minutes (Fig. $7 \mathrm{~m}$ ). The treated plantlets were air-dried for a while on papers then planted in a mixture of burned-rice husk and organic manure $(1: 1 . \mathrm{v} / \mathrm{v})$ on plastic trays with 40 holes, each hole was cultured one plantlet. The trays with plantlets cultured were covered with transparent plastic for one month. Every week the acclimatized plantlets were sprayed with $1 \mathrm{~g} / \mathrm{l}$ of Growmore (32-10-10). The experiment was arranged in CRD with 4 replications. Each treatment consisted one tray. Each tray planted 40 plantlets. Total plantlets used in each traetment were 160 plantlets, while total plantlets used in the experiment were 800 plantlets.

\section{Variables and parameters}

Variables and parameterobserved in the study were (1) Explant growth response, (2) Percentage of explant regeneration (\%), (3) Shoot initiation period (day), (4) Number of regenerated explants, (5) Number of shoots per explant, (6) Number of shoots produced per subculture period, (7) Height of leaves $(\mathrm{cm})$, (8) Number of leaves per explant or shoot subcultured, (9) Shoot multiplication rate (Number of shoots and leaves produced per subculture period), (10) Root initiation period (day), (11) Number of roots per shoot, (12) Root length (cm), (13) Percentage of survivability (\%), (14) Number of survival plantlets and Quality of plants.

Explant growth response was valued by observing alteration of explant in response to culture media from initiation stage to shoot formation under periodical observation of 1-2 days each. Percentage of explant regeneration (\%) was calculated by counting number of regenerated-explants divided by total explant cultured times by $100 \%$. Shoot and root initiation period was counted from initiation culture till initial shoot and root clearly observed. Shoot multiplication rate was calculated by counting number of shoots produced per shoot in the end of culture divided by total number of shoots cultured in the initial culture. Percentage of survivability (\%) was calculated by counting number of survival plantlets divided by total plantlets acclimatized times by $100 \%$. Quality of plants was valued from plant growth and performances. Final observation and variables measurement were carried out 1.5-2.0 months after culture.

\section{Analysis of data}

Collected data derived from these experiments were carried out by analysis of variance (ANOVA) using SAS Release Windows 9.2. If there was a significant different between means, the mean values were further analized using Tukey test, $\mathrm{p}=0.05$ (Mattjik and Sumertajaya, 2006).

\section{Results and Discussion}

Effect of TCL types and slicing positions on shoot initiation

Under periodical observation it was clearly noted that initiation of shoots was occurred on 15-20 days after culture by immercing small nodulars, especially in meristematic areas of apical dome, specifically on first slicing position of tTCL explant (Fig. 7c). Small nodulars continually grew and developed into initial shoots and were easily observed 30-35 days after culture. Number of initial shoots in the stage was varied from 0-9 initial shoots. The initial shoots became shoots with 0-7 shoots per explant and 1-3 leaves per explant were obviously recorded \pm 2 months after culture (Fig. 7d). Condition was generally recorded on tTCL treatment, while the ITCL explants produced lower results. The ITCL explants regenerated from 0-3 shoots per explant with 1-2 leaves per explant (Fig. 7e).

In the experiment, it was revealed that TCL types and slicing positions gave significant effect on shoot initiation statistically. tTCL was the suitable TCL type in stimulating higher shoot initiation compared to the lTCL. The TCL type produced 1.2 shoot per explant with 2.2 leaves per explant (Fig. 1A). Furthermore the first slicing position was the most apropriate slicing position in inducing higher shoot initiation with 1.5 shoots per explant and 3.1 leaves per explant (Fig. 1B). While combination of the first slicing position of tTCL was the most suitable combination treatment in obtaining high shoot initiation. The combination resulted in 3 shoots per explant with 6.1 leaves per explant (Table 1 and 2). Other combination stimulated lower results with the lowest results indicated by the fourth slicing position of ITCL type.

\section{Effect of slicing positions and responses of varieties on shoot} initiation

In the second experiment, it was also revealed that slicing positions and responses of varieties exhibited significant effect on shoot initiation. The first slicing position kept the most suitable explant for shoot initiation. The explant stimulated number of shoots per explant up to 5.3 shoots with 10.4 leaves per explant (Fig. 2A). Furthermore 'Black Jack' was the most responsive variety in shoot initiation with 3 shoots per explant and 5.5 leaves per explant (Fig. 2B). While combination treatment of the first slicing position of 'Black Jack' shoot tips were optimal combination on the shoot initiation of gerbera (Fig. $7 \mathrm{f}$ and $7 \mathrm{~g}$ ). The combination induced number of shoots per explant as high as 7.0 shoots with 13.5 leaves pes explant (Table 3 and 4). Other combination resulted in low shoot initiation with the lowest results indicated by 4th slicing position in all varieties. 

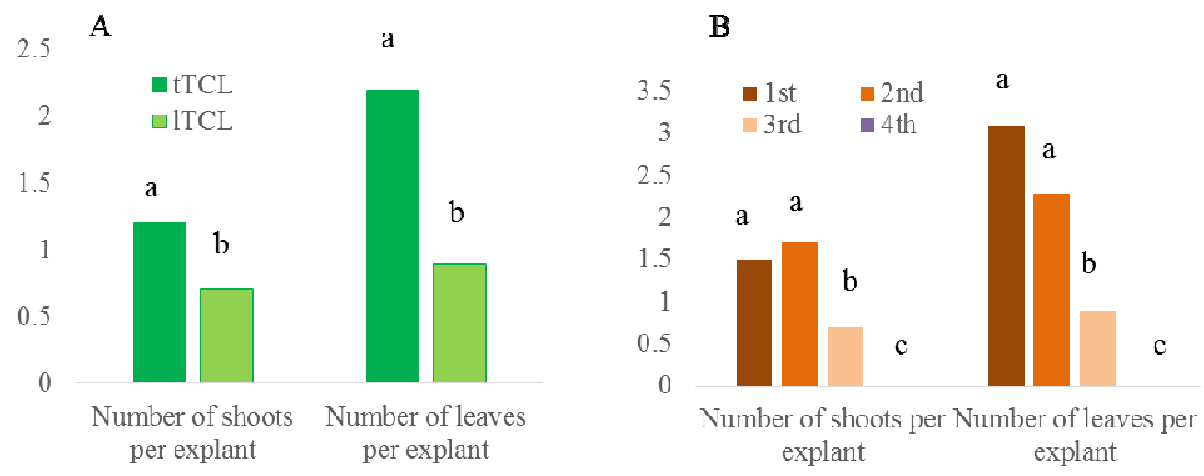

Fig. 1. Effect of TCL types and slicing positions on shoot initiation. A. Effect of TCL types on shoot initiation, B. Effect of slicing positions on shoot initiation. Histograms followed by the same letter in the same cluster are not significant different based on Tukey test, $\mathrm{p}=0.05$.

Table 1. Interaction effect of TCL types and slicing positions on number of shoots per explant

\begin{tabular}{ccccc}
\hline \multirow{2}{*}{ TCL type } & \multicolumn{3}{c}{ Slicing position } & $3^{\text {rd }}$ \\
\cline { 2 - 5 } & $1^{\text {st }}$ & $2^{\text {nd }}$ & $0.0 \mathrm{~b}$ & 0.0 \\
\hline tTCL & $3.0 \mathrm{a}$ & $1.8 \mathrm{a}$ & $1.4 \mathrm{a}$ & 0.0 \\
ITCL & $0.0 \mathrm{~b}$ & $1.6 \mathrm{a}$ & 10.45 & - \\
CV $(\%)$ & 13.17 & 9.76 & \\
\hline
\end{tabular}

Means followed by the same letter in the same column are not significant different based on Tukey test, $\mathrm{p}=0.05$.

Table 2. Interaction effect of TCL types and slicing positions on number of leaves per explant

\begin{tabular}{ccccc}
\hline \multirow{2}{*}{ TCL type } & \multicolumn{3}{c}{ Slicing position } \\
\cline { 2 - 5 } & $1^{\text {st }}$ & $2^{\text {nd }}$ & $3^{\text {rd }}$ & $4^{\text {th }}$ \\
\hline tTCL & $6.1 \mathrm{a}$ & $2.8 \mathrm{a}$ & $0.0 \mathrm{~b}$ & 0.0 \\
ITCL & $0.0 \mathrm{~b}$ & $1.9 \mathrm{a}$ & $1.9 \mathrm{a}$ & 0.0 \\
CV $(\%)$ & 13.90 & 15.42 & 12.56 & - \\
\hline
\end{tabular}

Means followed by the same letter in the same column are not significant different based on Tukey test, $\mathrm{p}=0.05$.

Table 3. Interaction effect of slicing positions and responses of varieties on number of shoots per explant

\begin{tabular}{|c|c|c|c|c|}
\hline \multirow{2}{*}{ Slicing position } & \multicolumn{4}{|c|}{ Responses of varieties } \\
\hline & 'Black Jack' & 'Carambole' & 'Nuance' & 'Violente' \\
\hline $1^{\mathrm{st}}$ & $7.0 \mathrm{a}$ & $5.3 \mathrm{a}$ & $3.5 \mathrm{a}$ & $5.3 \mathrm{a}$ \\
\hline $2^{\text {nd }}$ & $4.3 \mathrm{~b}$ & $2.3 \mathrm{~b}$ & $2.3 \mathrm{ab}$ & $3.3 \mathrm{~b}$ \\
\hline $3^{\text {rd }}$ & $0.8 \mathrm{c}$ & $0.5 \mathrm{c}$ & $1.3 \mathrm{bc}$ & $1.0 \mathrm{c}$ \\
\hline $4^{\text {th }}$ & $0.0 \mathrm{c}$ & $0.0 \mathrm{c}$ & $0.3 \mathrm{c}$ & $0.0 \mathrm{c}$ \\
\hline $\mathrm{CV}(\%)$ & 13.97 & 14.69 & 18.36 & 13.91 \\
\hline
\end{tabular}

Means followed by the same letter in the same column are not significant different based on Tukey test, $\mathrm{p}=0.05$.

Table 4. Interaction effect of slicing positions and responses of varieties on number of leaves per explant

\begin{tabular}{ccccc}
\multirow{2}{*}{ Slicing position } & \multicolumn{5}{c}{ Responses of varieties } \\
\cline { 2 - 5 } & 'Black Jack' & 'Carambole' & 'Nuance' & 'Violente' \\
\hline $1^{\text {st }}$ & $13.5 \mathrm{a}$ & $12.0 \mathrm{a}$ & $6.8 \mathrm{a}$ & $9.5 \mathrm{a}$ \\
$2^{\text {nd }}$ & $7.3 \mathrm{~b}$ & $5.3 \mathrm{~b}$ & $4.0 \mathrm{~b}$ & $6.5 \mathrm{a}$ \\
$3^{\text {rd }}$ & $1.3 \mathrm{c}$ & $0.8 \mathrm{c}$ & $2.0 \mathrm{bc}$ & $1.8 \mathrm{~b}$ \\
$4^{\text {th }}$ & $0.0 \mathrm{c}$ & $0.0 \mathrm{c}$ & $0.3 \mathrm{c}$ & $0.0 \mathrm{~b}$ \\
$\mathrm{CV}(\%)$ & 19.16 & 16.82 & 19.39 & 17.19 \\
\hline
\end{tabular}

Means followed by the same letter in the same column are not significant different based on Tukey test, $\mathrm{p}=0.05$. 

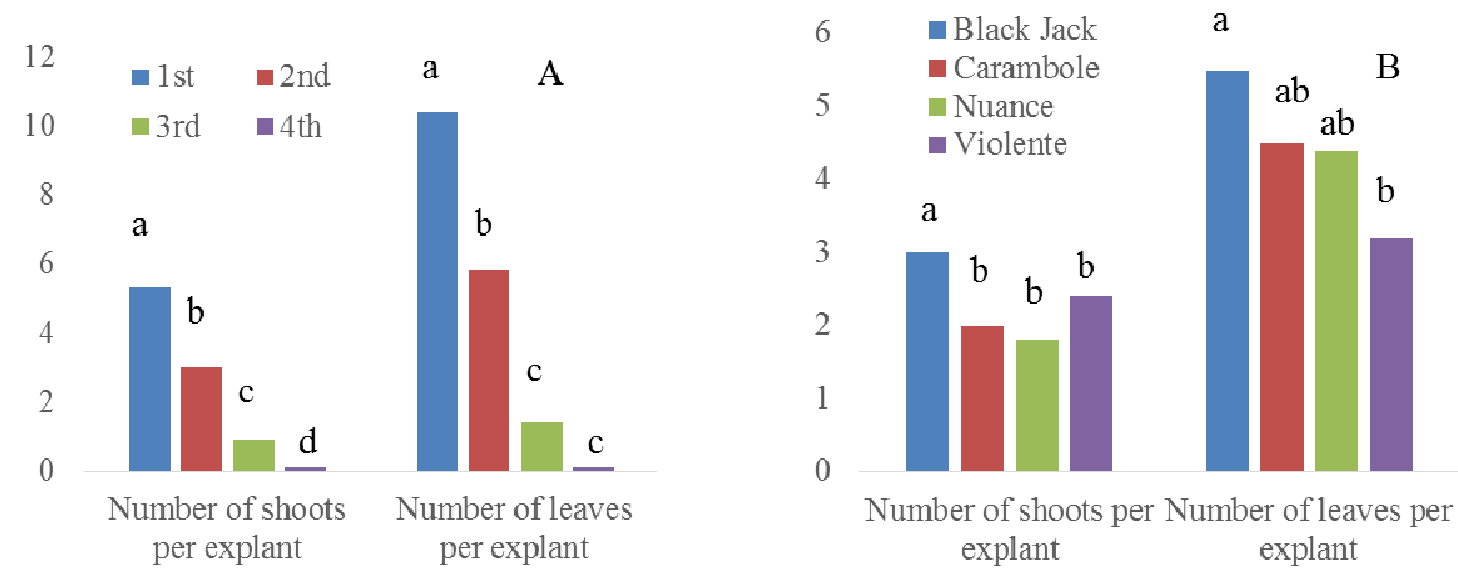

Fig. 2. Effect of slicing positions and responses of varieties on shoot initiation. A. Effect of slicing positions on shoot initiation. B. Effect of responses of varieties on shoot initiation, B. Histograms followed by the same letter in the same cluster are not significant different based on Tukey test, $\mathrm{p}=0.05$.

Response of Gerbera varieties-clones and adenine sulphate concentrations on shoot proliferation

In proliferation of shoots, it was clearly revealed that new shoots derived in the stage generally raised from existing axillary shoots (Fig. 7h). New initial shoots were regenerated 5-7 days after culture. Shoot primordia grew and produced new leaves with their young petioles. The new leaves with young petioles increased gradually in number and size in keeping with incubation period. In the end of culture number of shoots, leaves and leaf length were varied with 2-11 shoots per shoot subcultured, 8-35 leaves per shoot subcultured and $1.4-3.2 \mathrm{~cm}$ length of leaves.

In the experiment it was known that different gerbera varieties-clones and concentrations of AS gave different responses on shoot proliferation. Clone of 01.098 was the most responsive clone on the shoot proliferation. The clone was able to produce new shoots up to 8.3 shoots per shoot subcultured with 30.8 leaves per shoot subcultured and 2.75 $\mathrm{cm}$ leaf length (Fig. 3A). Another clone and varieties stimulated lower results in all variables observed. Furthermore $80 \mathrm{mg} / \mathrm{l}$ AS was the most appropriate concentration for proliferation of shoots. The concentration induced 5.0 shoots per shoot subcultured with 19.1 leaves per shoot subcultured and $2.63 \mathrm{~cm}$ length of leaves (Fig. 3B). Other concentrations generally reduced proliferation capacity of shoot in producing new shoots. While application of $20 \mathrm{mg} / \mathrm{l}$ AS for 01.098 clone was the most suitable combination treatment in obtaining high shoot proliferation. The best combination treatment successfully produced 9.4 shoots per shoot subcultured with 34.1 leaves per shoot subcultured and $2.37 \mathrm{~cm}$ length of leaves (Table 5, 6 and 7; Fig. 7i), however there was no significant difference compared to $0 \mathrm{mg} / \mathrm{l}$ AS for the same clone, whereas the lowest results were exhibited by $80 \mathrm{mg} / \mathrm{l}$ AS for 'Black Jack' variety.

From the study, it was also clearly proved that different varieties and clones had different responses on different concentrations of AS applied. Each variety/clone had different suitabilities and mostly there were no significant effect of AS on shoot initiation and growth. There were inconsistence effects of AS in shoot proliferation. Increasing AS concentration did not lead to increasing number of shoots produced per shoot subcultured. In the study, it was revealed that culture medium without application of AS gave higher results compared to the culture medium with AS. Therefore for multiplication of shoots, there was no utilization of AS anymore in the culture media.

\section{Multiplication of shoots}

In the multiplication of shoots, there were similar trends on increasing number of shoots and leaves produced per subculture period on half-strength MS medium containing $0.25 \mathrm{mg} / \mathrm{l} \mathrm{BAP}, 20 \mathrm{~g} / \mathrm{l}$ sucrose and $7 \mathrm{~g} / \mathrm{l}$ Swallow agar. In the first subculture, number of shoots produced per a shoot

Table 5. Interaction effect of responses of varieties-clones and different concentrations of adenine sulphate on number of shoots produced per shoot subcultured

\begin{tabular}{|c|c|c|c|c|c|}
\hline $\begin{array}{c}\text { AS concentration } \\
(\mathrm{mg} / \mathrm{l})\end{array}$ & 'Black Jack' & 'Carambole' & 'Nuance' & 01-098 clone & 11.46 clone \\
\hline 0 & $3.7 \mathrm{ab}$ & $3.8 \mathrm{ab}$ & $3.6 \mathrm{a}$ & $9.0 \mathrm{a}$ & $4.6 \mathrm{a}$ \\
\hline 20 & $4.0 \mathrm{a}$ & $2.9 \mathrm{~b}$ & $4.3 \mathrm{a}$ & $9.4 \mathrm{a}$ & $3.9 \mathrm{ab}$ \\
\hline 40 & $2.7 \mathrm{~b}$ & $3.7 \mathrm{ab}$ & $3.9 \mathrm{a}$ & $8.7 \mathrm{ab}$ & $3.9 \mathrm{ab}$ \\
\hline 60 & $4.0 \mathrm{a}$ & $3.4 \mathrm{ab}$ & $4.2 \mathrm{a}$ & $7.8 \mathrm{bc}$ & $4.6 \mathrm{a}$ \\
\hline 80 & $2.7 \mathrm{~b}$ & $4.5 \mathrm{ab}$ & $4.4 \mathrm{a}$ & $8.6 \mathrm{ab}$ & $5.1 \mathrm{a}$ \\
\hline 100 & $3.3 \mathrm{ab}$ & $5.0 \mathrm{a}$ & $4.3 \mathrm{a}$ & $6.8 \mathrm{c}$ & $3.2 \mathrm{~b}$ \\
\hline CV (\%) & 15.24 & 20.72 & 10.42 & 5.80 & 13.20 \\
\hline
\end{tabular}


Table 6. Interaction effect of responses of varieties-clones and different concentrations of adenine sulphate on number of leaves produced per shoot subcultured

\begin{tabular}{|c|c|c|c|c|c|}
\hline AS concentration $(\mathrm{mg} / \mathrm{l})$ & 'Black Jack' & 'Carambole' & 'Nuance' & 01-098 clone & 11.46 clone \\
\hline 0 & $11.6 \mathrm{ab}$ & $13.8 \mathrm{ab}$ & $14.8 \mathrm{~b}$ & $31.5 \mathrm{a}$ & $16.2 \mathrm{ab}$ \\
\hline 20 & $12.7 \mathrm{a}$ & $11.6 \mathrm{~b}$ & $16.9 \mathrm{ab}$ & $34.1 \mathrm{a}$ & $16.3 \mathrm{ab}$ \\
\hline 40 & $10.1 \mathrm{ab}$ & $14.5 \mathrm{ab}$ & $15.7 \mathrm{ab}$ & $31.6 \mathrm{a}$ & $14.2 \mathrm{bc}$ \\
\hline 60 & $13.1 \mathrm{a}$ & $14.9 \mathrm{ab}$ & $16.8 \mathrm{ab}$ & $29.5 \mathrm{ab}$ & $15.3 \mathrm{bc}$ \\
\hline 80 & $8.7 \mathrm{~b}$ & $16.3 \mathrm{a}$ & $18.9 \mathrm{a}$ & $32.0 \mathrm{a}$ & $19.8 \mathrm{a}$ \\
\hline 100 & $10.8 \mathrm{ab}$ & $17.3 \mathrm{a}$ & $17.4 \mathrm{ab}$ & $26.0 \mathrm{~b}$ & $11.3 \mathrm{c}$ \\
\hline CV (\%) & 12.86 & 14.09 & 8.77 & 7.09 & 11.86 \\
\hline
\end{tabular}

Table 7. Interaction effect of responses of varieties-clones and different concentrations of adenine sulphate on length of leaves $(\mathrm{cm})$

\begin{tabular}{cccccc}
\hline AS concentration $(\mathrm{mg} / \mathrm{l})$ & 'Black Jack' & 'Carambole' & 'Nuance' & $01-098$ clone & 11.46 clone \\
\hline 0 & $1.68 \mathrm{a}$ & $1.85 \mathrm{a}$ & $2.41 \mathrm{ab}$ & $2.44 \mathrm{~b}$ & $2.54 \mathrm{a}$ \\
20 & $1.50 \mathrm{a}$ & $2.11 \mathrm{a}$ & $2.24 \mathrm{ab}$ & $2.37 \mathrm{~b}$ & $2.59 \mathrm{a}$ \\
40 & $1.64 \mathrm{a}$ & $2.02 \mathrm{a}$ & $1.82 \mathrm{~b}$ & $2.50 \mathrm{~b}$ & $2.18 \mathrm{a}$ \\
60 & $1.90 \mathrm{a}$ & $1.96 \mathrm{a}$ & $2.56 \mathrm{ab}$ & $2.60 \mathrm{~b}$ & $2.61 \mathrm{a}$ \\
80 & $1.86 \mathrm{a}$ & $2.36 \mathrm{a}$ & $2.78 \mathrm{a}$ & $3.32 \mathrm{a}$ & $2.86 \mathrm{a}$ \\
$\mathrm{CV}(\%)$ & $1.55 \mathrm{a}$ & $2.14 \mathrm{a}$ & $2.31 \mathrm{ab}$ & $3.31 \mathrm{a}$ & $2.67 \mathrm{a}$ \\
\hline
\end{tabular}
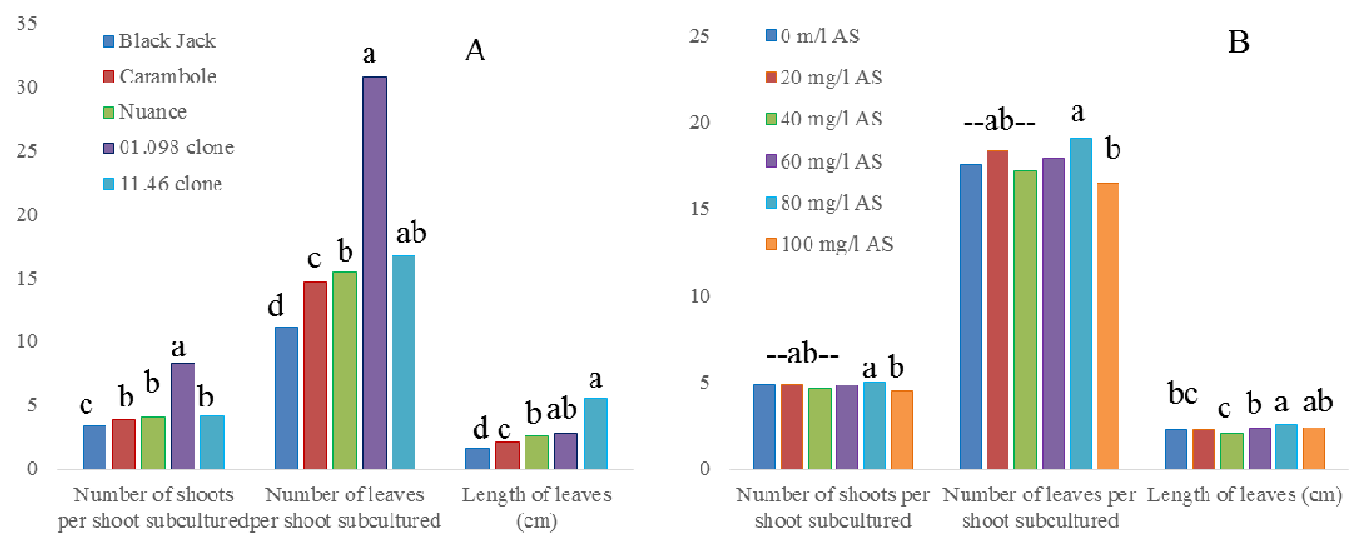

Fig. 3. Effect of different concentrations of AS and responses of gerbera varieties-clone on shoot proliferation. A. Effect of different varieties-clones on shoot proliferation. B. Effect of AS concentrations on shoot proliferation, B. Histograms followed by the same letter in the same cluster are not significant different based on Tukey test, $\mathrm{p}=0.05$.

subcultured was varied from 3-6 regenerated-shoots with 11.4-11.6 leaves, 3-8 initiated shoots with 11.6-23.8 leaves in the second subculture, 4-10 shoots with 17.6-34.1 leaves in the third subculture, 6-11 shoots with 16.7-38.8 leaves in the fourth subculture and reduced afterward. The highest shoot production was established in the fourth subculture, however high quality of regenerated-shoots could be maintained till the sixth to seventh subculture. Reduction of shoots observed started from fifth subculture was indicated by immersing of 1-3 roots per shoot cluster and 1-2 yellowing leaves per shoot cluster in the sixth or seventh subculture.

Based on shoot multiplication rate (SMR) it was noted that 01.098 clone was the most responsive of gerbera with the highest SMR as high as 7.3. The clone successfully produced high number of shoots in each subculture period, however the highest number of shoots as high as 10.2 shoots was noted on 'Carambole' in the fourth subculture period.
The second best SMR of 5.7 was indicated by 'Carambole', while the lowest SMR was recorded on 11.46 clone (Fig.4). Increasing number of regenerated shoots let to enhancing number of leaves produced with slightly different trends in line pattern (Fig.5).

Root formation responses of Gerbera varieties-clones on different rooting media

In root formation study, initial roots regenerated in bottom parts of stem were clearly observed 5-10 days after culture in the most of shoots cultured, while others did not produce root till 16 days of culture, especially on halfstrength MS medium containing $0.1 \mathrm{mg} / \mathrm{l} \mathrm{BAP}$ and 0.5 mg/l NAA (Fig. 7j). Number of regenerated-roots derived from the experiment was varied from $0-4$ roots per shoot with $0-4 \mathrm{~cm}$ in root length. There were significant different root formation responses of Gerbera varieties-clones on different rooting media statistically $(\mathrm{p}=0.05)$. 
70

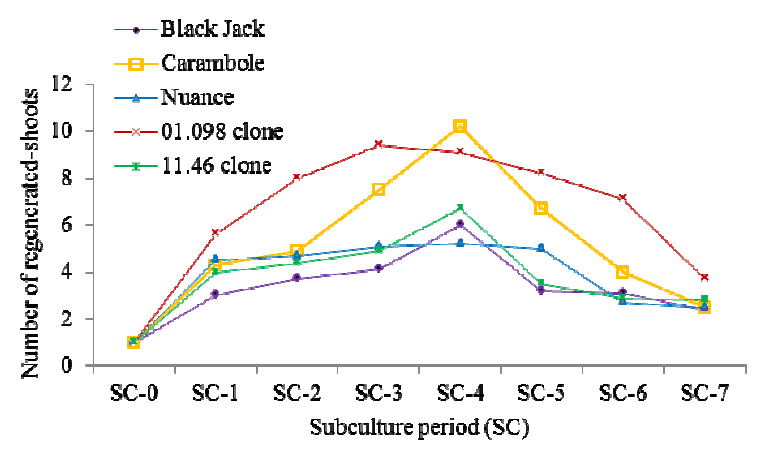

Fig. 4. Number of regenerated-shoots derived from different responses of Gerbera varieties-clones under periodical subculture every 1.5 months

The both treatments also gave significant interaction effect in all variables observed, where different types of rooting media gave higher effects compared to responses of Gerbera varieties-clones.

The 11.46 clone was the most responsive gerbera in root initiation, however higher number of roots was determined on 'Black Jack' and 'Nuance' in faster growth of roots (Fig. 6A). Half-strength MS medium supplemented with $0.1 \mathrm{mg} / \mathrm{l} \mathrm{BAP}, 0.5 \mathrm{mg} / \mathrm{NAA}$ and $1.5 \mathrm{~g} / \mathrm{l} \mathrm{AC} \mathrm{(RM-2)}$ was the most suitable medium for root formation (Fig. $7 \mathrm{k}$ ). The medium successfully regenerated roots in 12.1 days after culture with 2.1 roots per shoot and $2.1 \mathrm{~cm}$ lengt of roots (Fig. 6B). Shoot of 'Nuance' cultured on RM-2 medium was the optimal combination treatment for root formation. The combination successfully stimulated initial roots in 12.6 days after culture with 2.4 roots per shoot and $2.5 \mathrm{~cm}$ length of roots (Table 8,9 ). The second-best combination treatment was performed by 11.46 shoot clone

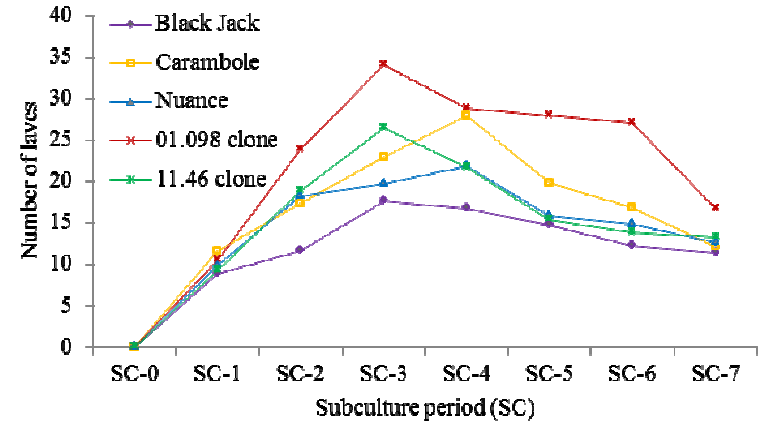

Fig. 5. Number of leaves derived from different responses of Gerbera varieties-clones under periodical subculture every 1.5 months

cultured on RM-2 medium, while lowest results were indicated by all gerberas cultured on RM-1. Most of shoots could not regenerate roots. From the study it was also clearly revealed that addition of AC in rooting medium had significant effect on root initiation and formation.

\section{Acclimatization of plantlets}

Acclimatization of plantlets derived from in vitro culture works of Gerbera generally can be easily carried out with high survivability of plantlets in ex vitro condition, when well and qualified rooted shoots, best medium, best plantlet handling and suitable treatments were applied. Well growth of plantlets with 3-8 leaves and 0.5-1.0 cm root length (Fig. $71)$, burned-rice husk + organic manure $(1: 1, \mathrm{v} / \mathrm{v})$, carefull handling, covering plantlets using transparent plastic for $15-$ 30 days lead to high successful acclimatization of plantlets. In the study, percentage of survival plantlets was $85-100 \%$ with the highest percentage of survivability as high as $100 \%$

Table 8. Interaction effect of responses of Gerbera varieties-clones and rooting media on number of roots produced per shoot

\begin{tabular}{|c|c|c|c|c|c|c|}
\hline \multirow[t]{2}{*}{ Gerbera variety-clone } & \multicolumn{2}{|c|}{$\begin{array}{l}\text { Initial root formation time } \\
\text { (day) }\end{array}$} & \multicolumn{2}{|c|}{$\begin{array}{c}\text { Number of roots produced per } \\
\text { shoot }\end{array}$} & \multicolumn{2}{|c|}{$\begin{array}{l}\text { Root length } \\
\qquad(\mathrm{cm})\end{array}$} \\
\hline & RM-1 & RM-2 & RM-1 & RM-2 & RM-1 & RM-2 \\
\hline 'Black Jack' & $15.2 \mathrm{a}$ & $12.2 \mathrm{ab}$ & $0.7 \mathrm{a}$ & $1.9 \mathrm{~b}$ & $0.2 \mathrm{a}$ & $3.1 \mathrm{a}$ \\
\hline 'Carambole' & $0.0 \mathrm{~b}$ & $12.1 \mathrm{ab}$ & $0.0 \mathrm{~b}$ & $2.0 \mathrm{ab}$ & $0.0 \mathrm{a}$ & $3.2 \mathrm{a}$ \\
\hline 'Nuance' & $14.5 \mathrm{a}$ & $12.6 \mathrm{a}$ & $0.8 \mathrm{a}$ & $2.4 \mathrm{a}$ & $0.4 \mathrm{a}$ & $2.5 \mathrm{ab}$ \\
\hline 01.098 clone & $0.0 \mathrm{~b}$ & $12.4 \mathrm{a}$ & $0.0 \mathrm{~b}$ & $1.9 \mathrm{~b}$ & $0.0 \mathrm{a}$ & $1.9 \mathrm{~b}$ \\
\hline 11.46 clone & $0.0 \mathrm{~b}$ & $11.3 \mathrm{~b}$ & $0.0 \mathrm{~b}$ & $2.2 \mathrm{ab}$ & $0.0 \mathrm{a}$ & $3.1 \mathrm{a}$ \\
\hline $\mathrm{CV}(\%)$ & 15.61 & 5.21 & 15.61 & 16.49 & 15.61 & 8.69 \\
\hline
\end{tabular}

Means followed by the same letter in the same column are not significant different based on Tukey test, $\mathrm{p}=0.05$.

Table 9. Data of plantlet acclimatization

\begin{tabular}{ccc}
\hline $\begin{array}{c}\text { Gerbera } \\
\text { variety-clone }\end{array}$ & $\begin{array}{c}\text { Percentage of survival plantlets } \\
(\%)\end{array}$ & $\begin{array}{c}\text { Number of survival } \\
\text { plantlets }\end{array}$ \\
\hline 'Black Jack' & $99.5 \mathrm{a}$ & $39.8 \mathrm{a}$ \\
'Carambole' & $100.0 \mathrm{a}$ & $40.0 \mathrm{a}$ \\
'Nuance' & $85.3 \mathrm{~b}$ & $34.0 \mathrm{~b}$ \\
01.098 clone & $85.3 \mathrm{~b}$ & $34.0 \mathrm{~b}$ \\
11.46 clone & $100.0 \mathrm{a}$ & $40.0 \mathrm{a}$ \\
$\mathrm{CV}(\%)$ & 7.89 & 7.83 \\
\hline
\end{tabular}

Means followed by the same letter in the same column are not significant different based on Tukey test, $\mathrm{p}=0.05$. 

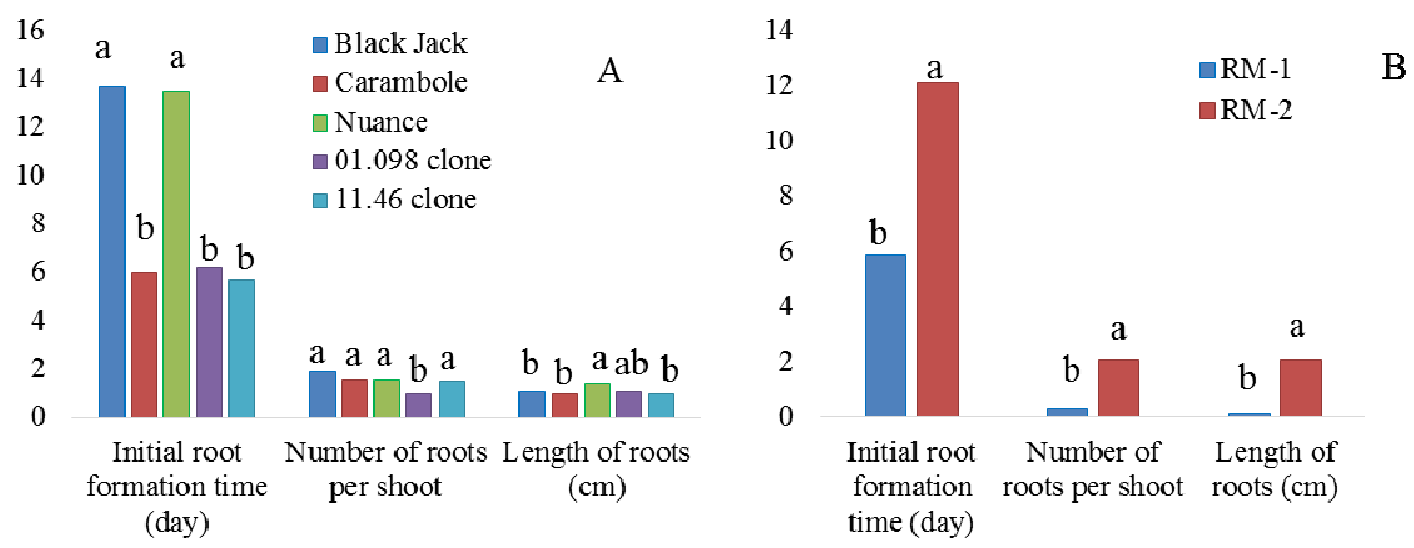

Fig. 6. Responses of Gerbera varieties-clones and rooting media on root initiation and formation. A. Responses of Gerbera varieties-clones on root initiation and formation, B. Effect of rooting media on root initiation and formation

established on 'Carambole' and 11.46 clone (Table 9; Fig. $7 \mathrm{n}$ and $7 \mathrm{o}$ ). In another word, in the both gerberas 40 plantlets transferred ex vitro condition survived and grew well after acclimatization, whereas death plantlets of 0 $14.7 \%$ were generally caused by severe dehydration. The symptom was generally initiated by pale leaves in the egde of them followed by wilting of them. The pale areas were developed broader and broader continually till all leaf areas to be pale then followed by its petiole pale and wilt. The accident was occurred in all leaves and petioles, one by one, till the youngest leaves and its petioles. When all leaves and petioles were pale and wilt, the plantlet was then dying (Fig. $7 \mathrm{p})$.

From the serial experiments it was revealed that in vitro mass propagation of gerbera via application of TCL and AS was successfully established. For initiation and proliferation of axillary shoots, the first slicing position of shoot tip tTCL cultured on half-strength MS medium supplemented with $0.25 \mathrm{mg} / \mathrm{BAP}$ was the best treatment in obtaining high proliferated shoots up to 3 shoots per explant in the first experiment and 7 shoots per explant in the second experiment. The first slicing position of tTCL gave higher and significantly effect compared to all slicing positions of ITCL. Results of the study indicated that tTCL explants, especially in the first slicing position that have different tissue types such as epidermal, cortical, cambium, perivascular and medullar tissue, parenchyma cells (Tran Thanh Van, 1980; Teixeira da Silva 2003ab, 2004; Teixeira da Silva et al., 2006) had high capacity in initiation and proliferation of axillary shoots. In different study, tTCL receptacle explants Gerbera cultured on MS medium containing $0.02 \mathrm{mg} / \mathrm{TDZ}, 0.8 \mathrm{mg} / \mathrm{l} \mathrm{AS}$ and $10 \%$ coconut water resulted in $57 \%$ shoot regeneration and higher compared to callus explants (Nhut et al., 2007). While in other studies, stem to shoot tip tTCL of Rhynchostylis gigantea with $0.3-0.5 \mathrm{~mm}$ in explant slicing thickness cultured on MS medium supplemented with $0.68 \mathrm{mg} / \mathrm{l}$ $\mathrm{BAP}$ and $0.66 \mathrm{mg} / \mathrm{l} \mathrm{TDZ}$ successfully regenerated $11.7 \mathrm{bud}$ per tTCL (Bui et al., 1999). tTCL bulb shoots of lilium in 0.2-0.4 mm slicing thickness cultured on MS medium augmented with $0.25 \mathrm{mg} / \mathrm{l} \mathrm{N}$-(2-chloro-4-pyridyl)-N'phenylurea (forchlofenuron, CPPU) successfully induced
16.8 shoot per explant (Le et al., 1999), tTCL cormel of Gladiolus spp. in $0.3-0.5 \mathrm{~mm}$ thickness of slicing explants produced 50 shoots per explant on MS medium fortified by 1-3 mg/l TDZ 3 weeks after culture (Stefaniak, 1994), tTCL Chrysanthemum internodus in $1-2 \mathrm{~mm}$ explant slicing thickness induced high adventitious shoots and embryos MS medium added with 1-2 mg/l TDZ or $2 \mathrm{mg} / \mathrm{l}$ BAP (Teixeira da Silva dan Fukai, 2003). 1-2 mm tTCL internodes of Ceropegia spiralis resulted in 11.4 shoots per explant on MS medium containing $3.0 \mathrm{mg} / \mathrm{l} \mathrm{BAP}$ and 0.25 mg/l 2,4-D (Murthy dan Kondamudi, 2011). Successful application of $\mathrm{tTCL}$ was also reported on Orchid, African violet, Geranium hybrid, sun flower, Heliconia, Iris. Gentian, etc. (Teixeira da Silva et al., 2006)

Application of adenine sulphate (AS) that succeed to increase explant capacity on shoot regeneration on in vitro culture of Chicorium intybus cv. Focus (Nandagopal and Kumari, 2006), Curcuma angustifolia (Shukla et al., 2007), Jatropha curcas (Datta et al., 2007), Picrorbiza scrophulariiflora (Bantawa et al., 2009), Thevetia peruviana (Zibbu and Batra, 2010), Trifolium repens (Gabriela, 2011), Begonia x hiemalis (Awal et al., 2013), Stevia rebaudiana (Khan et al., 2014) gave less and inconsistance effect on shoot initiation and proliferation of gerbera axillary shoots. In C. intybus 'Focus', MS and B5 medium supplemented with $1.5 \mathrm{mg} / \mathrm{l} \mathrm{BAP}, 0.5 \mathrm{mg} / \mathrm{l} \mathrm{IAA}$ and $500 \mathrm{mg} / \mathrm{l} \mathrm{AS}$ was able to induce 25 shoots per explant on initiation stage (Nandagopal dan Kumari, 2006).

MS medium containing $3 \mathrm{mg} / \mathrm{l} \mathrm{BAP}$ and $25 \mathrm{mg} / \mathrm{l} \mathrm{AS}$ stimulated shoot formation up to 6 micro-shoots per explant in in vitro culture of $C$. angustifolia (Shukla et al., 2007), MS medium fortified by $100 \mathrm{mg} / \mathrm{l}$ Bavistin and 100 $\mathrm{mg} / \mathrm{l}$ AS induced 28 shoots per explant $P$. scrophulariiflora (Bantawa et al., 2009), 3-4 shoots per explant of $T$. peruviana were resulted in MS medium containing $2 \mathrm{mg} / \mathrm{l}$ 2,4-D, $1 \mathrm{mg} / \mathrm{l} \mathrm{Kin}$ and $0.25 \mathrm{mg} / \mathrm{l} \mathrm{AS}$ (Zibbu and Battra, 2010), 38 shoots per explant of T. repens were regenerated on MS medium with $2 \mathrm{mg} / \mathrm{l}$ Zeatin, $0.1 \mathrm{mg} / \mathrm{l}$ indole-3-asetic acid (IAA) and $40 \mathrm{mg} / \mathrm{l}$ AS (Gabriela, 2011); 94 shoots per explant of Begonia $\times$ hiemalis on MS medium augmented with $1 \mathrm{mg} / \mathrm{l} \mathrm{BAP}, 1.0 \mathrm{mg} / 1 \mathrm{NAA}$ and $40 \mathrm{mg} / \mathrm{l} \mathrm{AS}$ (Awal et 
72
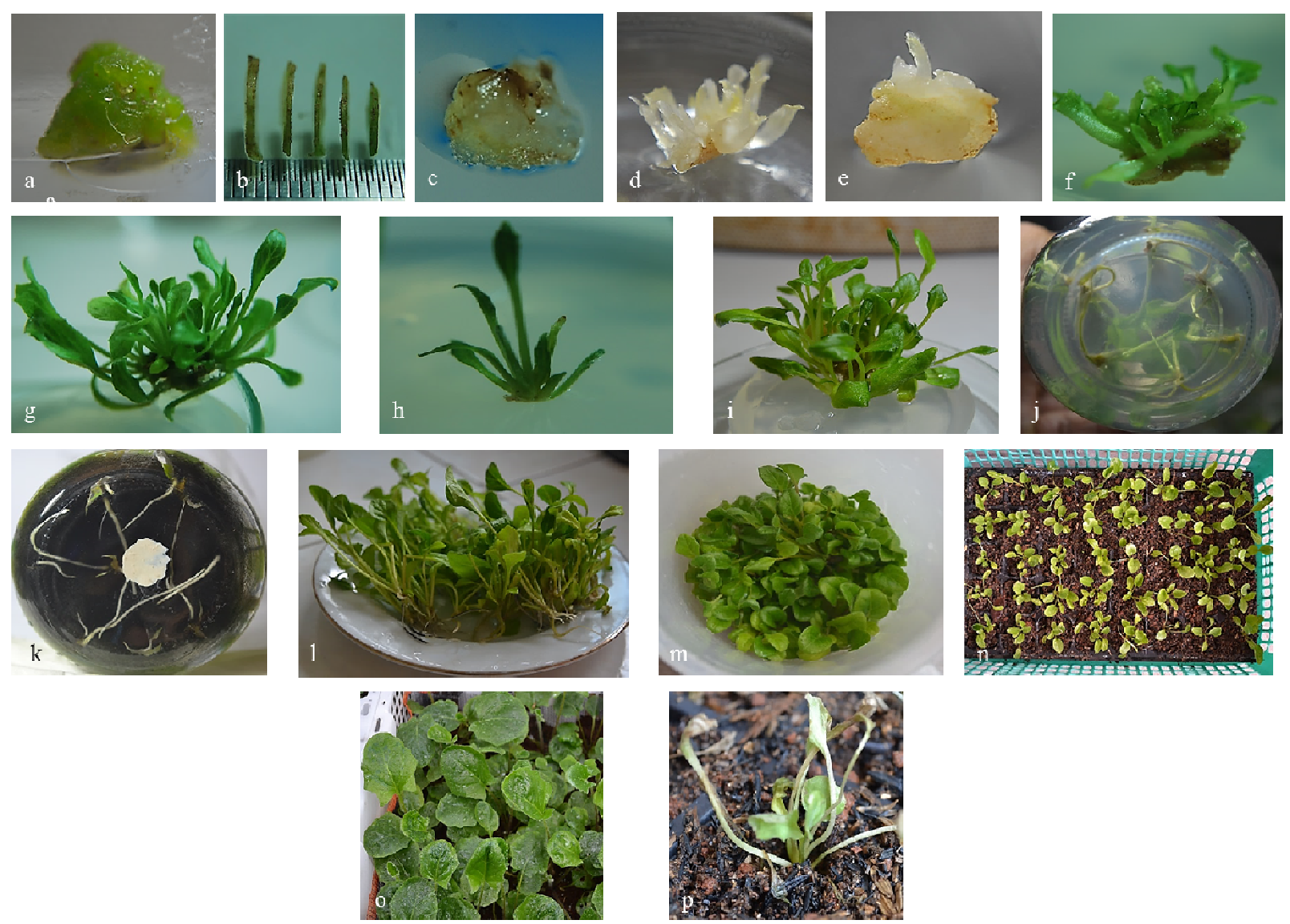

Fig. 7. Axillary shoot initiation to its acclimatization derived from TCL explants and adenine sulphate application in in vitro mass propagation protocol of gerbera. a. Enlarged-shoot tip ready used as explant source for TCL treatment resulted from culturing the shoot tip on half-strength MS medium supplemented with $1.5 \mathrm{mg} / \mathrm{l} \mathrm{TDZ}$ and $0.25 \mathrm{mg} / \mathrm{BA} \pm 2$ months after culture. b. Sizes of slicing explants used for tTCL and ITCL were $<1.0 \mathrm{~mm}$. c. Regenerated small nodulars on the first slicing position of tTCL explant of 'Black Jack' on half-strength MS medium containing $0.25 \mathrm{mg} / \mathrm{l}$ BAP 16 days after dark incubation in the first experiment, d. Regenerated shoots derived from the first slicing positon of tTCL explant of 'Black Jack' on half-strength MS medium containing $0.25 \mathrm{mg} / \mathrm{l}$ BAP 30 days after dark incubation in the first experiment, e. Regenerated shoots derived from ITCL explant on half-strength MS medium containing $0.25 \mathrm{mg} / \mathrm{l}$ BAP 35 days after dark incubation in the first experiment, $\mathrm{f}$. Regenerated shoots derived from the first slicing positon of tTCL explant of 'Black Jack' on half-strength MS medium containing $0.25 \mathrm{mg} / \mathrm{l}$ BAP 1.5 months after dark incubation in the second experiment, g. Regenerated shoots derived from the first slicing positon of tTCL explant of 'Black Jack' on half-strength MS medium containing $0.25 \mathrm{mg} / \mathrm{l}$ BAP 2.0 months after dark incubation in the second experiment, h. Single shoot cultured on half-strength MS medium supplemented with $0.25 \mathrm{mg} / \mathrm{l} \mathrm{BAP} 5$ days after subculture for shoot multiplication purpose, i. Proliferated shoots derived from single shoot cultured on half-strength MS medium supplemented with $0.25 \mathrm{mg} / \mathrm{l} \mathrm{BAP}$ and $60 \mathrm{mg} / \mathrm{l} \mathrm{AS} 1.5$ months after culture, j. Rooting shoots on half-strength MS medium containing $0.1 \mathrm{mg} / \mathrm{l} \mathrm{BAP}$ and $0.5 \mathrm{mg} / \mathrm{l} \mathrm{NAA}$ without AC 1.0 month after culture. k. Rooting shoots on half-strength MS medium containing $0.1 \mathrm{mg} / \mathrm{l} \mathrm{BAP}$ and $0.5 \mathrm{mg} / \mathrm{l} \mathrm{NAA}$ with $2 \mathrm{~g} / \mathrm{l} \mathrm{AC} 1.5$ month after culture, 1 . Plantlets with $4-9$ leaves and 2-6 roots ready for acclimatization, $\mathrm{m}$. Plantlets treated with 1\% pesticide solution (fungicide and bactericide) for 3 min before their planting in acclimatization media, n. Growth of plantlets 15 days after acclimatization, o. Vigorous and healthy plantlet growth 2.5 months after acclimatization, p. Plantlet with wilted leaves due to dehydration 10 days after acclimatization. 
al., 2013) and 25 shoots per explant on $S$. rebaudiana established on MS medium fortified by $2.0 \mathrm{mg} / 1 \mathrm{Kin}$ and 40 $\mathrm{mg} / \mathrm{l}$ AS (Khan et al., 2014); whereas in the study 7.0 shoots per explant were resulted in half-strength MS medium containing $0.25 \mathrm{mg} / \mathrm{l} \mathrm{BAP}$ and $60 \mathrm{mg} / \mathrm{l} \mathrm{AS}$ for initial proliferation stage. While in the shoot multiplication stage, high concentration of AS let to reducing number of shoots regenerated, reducing the AS concentration down to 20 $\mathrm{mg} / \mathrm{l}$ produced high number of shoots per explant up to 9.4 shoots on 01.098 clone, but there was no significant different compared to half-strength MS medium with 0.25 $\mathrm{mg} / \mathrm{l} \mathrm{BAP}$ and AS free. Therefore, there was no application of AS anymore in the multiplication stage of shoots.

Growth pattern and increasing number of shoots till initiation of adventitious roots in the multiplication stage of shoots were significantly affected by alteration ratio of IAA and abscisic acid (ABA) and periodical subculture (Noiton et al., 1992). In the initial multiplication stage, IAA-ABA ratio was less than 0.2 , while in the fourth subculture period, IAA-ABA ratio was on 0.7 in in vitro culture of apple (Noiton et al., 1992). Alteration of IAA-ABA ratio and periodical subculture reduced capacity of shoots to regenerate new shoots and increased capability of shoots to stimulate adventitious roots. In the study, increasing number of shoots produced was noted from the first till fourth subculture period and reduced thereafter, but qualified shoots could be stimulated till the sixth or seventh subculture. One to three roots per shoot cluster was recorded in the fifth subculture period and 1-2 yellowing leaves per shoot cluster were noted in the sixth or seventh subculture period. Almost similar results were established in the previous study (Winarto and Yufdy, 2017). In the previous study, the highest shoots produced were determined in the fifth subculture period and declined afterward, while qualified shoots could be induced till the eighth subculture. Similar results were also reported on in vitro culture of $G$. jamesonii 'Victoria' (Vardja dan Vardja, 2001). Whereas in other plants, the highest shoots regenerated were noted in the fourth subculture and reduced thereafter on Lisianthus (Winarto et al., 2014), the highest shoots produced recorded in the third subculture and maintained qualified-shoots till seventh subculture were established in in vitro culture of Ruscus bypophyllum (Winarto and Setyawati, 2014), fourth and sixth subculture on Dendrobium 'Gradita 31' and D. 'Zahra FR 62' (Winarto, 2012), and third and sixth subculture for Cherry (Vujović et al., 2012).

Preparing well rooted-shoots on in vitro culture of Gerbera is one of critical factors for their acclimatization stage. Induction of the roots was significantly affected by culture media and additive substances, especially activated charcoal (AC). Application of AC in in vitro rooting can shorthen root initiation period and increase number and quality of roots (Sharma et al., 2007; Gantait et al., 2009; Khatun et al., 2010). In the study, application of $1.5 \mathrm{~g} / \mathrm{l} \mathrm{AC}$ on half-strength MS medium containing $0.1 \mathrm{mg} / \mathrm{l} \mathrm{BAP}$ and $0.5 \mathrm{mg} / \mathrm{l} \mathrm{NAA}$ was able to initiate root formation in $\mathbf{1 2 . 6}$ days after culture with 2.4 roots per shoot and $2.5 \mathrm{~cm}$ root length. In D. chrysotoxum, $2.0 \mathrm{~g} / 1 \mathrm{AC}$ in MS medium hormone free induced root formation in 21.7 days after culture with 4.3 root per shoots and $5.0 \mathrm{~cm}$ length of roots
(Gantait et al., 2009), $1 \mathrm{~g} / \mathrm{l} \mathrm{AC}$ on MS medium fortified by $1.0 \mathrm{mg} / \mathrm{l} \mathrm{IAA}$ and $1.0 \mathrm{mg} / \mathrm{l} \mathrm{IBA}$ stimulated 6.6 roots per shoot and $5.4 \mathrm{~cm}$ length of roots of Dendrobium (Khatun et al., 2010), $1 \mathrm{~g} / \mathrm{l} \mathrm{AC}$ in half-strength MS medium supplemented with $2.0 \mathrm{mg} / \mathrm{l} \mathrm{IBA}$ induced 16.0 roots per shoot with $7.5 \mathrm{~cm}$ root length of Hydrangea macrophylla (Dahab, 2006), $500 \mathrm{mg} / \mathrm{A} \mathrm{AC}$ in half-strength MS medium hormone free initiated 4.5 roots per shoot with $2.1 \mathrm{~cm}$ root length of Punica granatum (Deepika dan Kanwar, 2010).

Acclimatization of plantlets derived from in vitro culture works of gerbera is one of crucial stage in establishing mass propagation protocol for the plant. Type of media and plantlet handling processes during acclimatization are important factors in the stage. In the preliminary studies, un-optimal medium (burned-rice husk) and plantlet handling processes let to reducing percentage of survivability and number of survival plantlets down to 0$16 \%$ and $0-5$ survival plantlets out of 30-50 plantlets acclimatized, respectively. In the stage, improvement plantlet handing processes started from preparing well and qualified plantlets followed by careful taking out from culture vessel, root rinsing under tap water and pesticide treatment, covering transparent plastic for 30 days, spraying Growmore high nitrogen every week $(1 \mathrm{~g} / \mathrm{l})$ and applying a mixture media of burned-rice husk and organic manure $(1: 1, \mathrm{v} / \mathrm{v})$ resulted in high percentage of survivability from $85-100 \%$ or $34-50$ survival plantlets. Almost similar results with 95\% survivability and 114 survival plantlets were reported on G. jamesonii 'Black Jack' (Winarto and Yufdy, 2017). While other gerbera's studies, 50-60\% survivability of plantlets were established in plastic pots $(10 \mathrm{~cm})$ containing a mixture of Farmyard manure (FYM): sand (1:1) (Kumar and Kanwar, 2006), 70-80\% survivability was established in a mixture of sand and barnyard manure (1:1, v/v) (Kumar and Kanwar, 2007), 92\% in autoclaved sand and perlite (1:1 ratio) (Shabanpour et al., 2012), 90\% on cocopeat (Bhargava et al., 2013), 66.7-90.0\% on a mixture of soil and peat (Shylaja et al., 2014), 84\% survival rate in peat + perlite mixture (2:1) (Gök et al., 2016).

In this study it was also clearly revealed that each plant genotype and/or explant have specific response and behavior in each in vitro culture step either initiation, proliferation or multiplication, root formation and acclimatization (Winarto, 2012; Winarto et al., 2013; Shintiavira and Winarto, 2014; Winarto, 2014; Winarto et al., 2016; Winarto and Yufdy, 2017). In the research, it was determined that shoot tip tTCL of 'Black Jack' was able to give better response than 'Violente' > 'Carambole' > 'Nuance' in initiation step. In the proliferation stage, 01.098 clone was more responsive than 'Carambole' > 'Black Jack' $>$ 'Nuance' > 11.46 clone; 11.46 clone had maximal response in shoot rooting compared to 'Carambole' > 01.098 clone > 'Nuance' > 'Black Jack'; and 11.46 clone similar to 'Carambole' exhibited higher response on acclimatization stage compared to 'Black Jack' > 'Nuance' = 01.098 clone. In other studies, 'Marleen' gave higher response than 'Red Marleen'>'Victoria'>'Lydi' on shoot proliferation (Vardja dan Vardja, 2001); AV108 clone>AV101 clone on shoot formation with $60 \%$ frequency of shoot formation and 14.3 shoots per explant (Aswath dan Choudhary, 2002); genotype $2>$ other 
74

genotypes on percentage of explant regeneration up to $95 \%$ and 5 shoots per tTCL (Nhut et al., 2007); 'Bonnie'>'Arianna'>'Menn'>'Tobia' on shoot initiation with 16 days initiation time and 6.6 shoots per explant (Son et al., 2011); red variety>yellow> white variety on shoot formation, root formation and acclimatization (Akter et al., 2012); shoot tip explants of $G$. jamesonii had higher regeneration capacity than leaves $>$ petioles $>$ petals in initiation stage of callus (Winarto and Yufdy, 2017). Based on the facts that each genotype and/or explant had specific response and behavior in the in vitro culture of plant, therefore development and establishment of in vitro mass propagation protocol are also unique and specific for each genotype.

\section{Conclusions}

Finally, from the study it can be concluded that a new in vitro propagation protocol derived from application of TCL and AS was sussessfully developed and established. Each step in developing the protocol had unique and specific results. In the initiation stage, first slicing position of 'Black Jack' shoot tip tTCL was the most optimal combination treatment to produce 3 shoots per explant with 6.1 leaves per explant in the first experiment and 7.0 shoots per explant with 13.5 leaves per explant in the second experiment. The first slicing position of tTCL 01.098 clone shoot tip explants and $20 \mathrm{mg} / \mathrm{l} \mathrm{AS}$ in half-strength MS medium containing $0.25 \mathrm{mg} / \mathrm{l} \mathrm{BAP}$ were the most combination treatment in obtaining the highest number of shoots produced per shoot subcultured up to 9.4 shoots per shoot subcultured with 34.1 leaves and $2.37 \mathrm{~cm}$ length of leaves in the proliferation stage, however the treatment did not give significant effect compared to control, so the AS treatment was not applied in further experiment due to inconsistence effect. Under periodical subcultures on halfstrength MS medium fortified by $0.25 \mathrm{mg} / \mathrm{l} \mathrm{BAP,} 20 \mathrm{~g} / \mathrm{l}$ sucrose and $7 \mathrm{~g} / \mathrm{l}$ Swallow agar, number of shoots and leaves increased gradually from the initial culture till the fourth subculture and decline thereafter. The highest SMR was established on 01.098 clone with as high as 7.3, however the qualified shoots could be produced till sixth to seventh subculture. Shoot quality reduction was indicated by immercing adventitious roots and leaf senescences. The well growth of plantlets was easily prepared by culturing shoots on half-strength MS medium supplemented with $0.1 \mathrm{mg} / \mathrm{l}$ BAP, $0.05 \mathrm{mg} / \mathrm{l} \mathrm{NAA}$ and $1.5 \mathrm{~g} / \mathrm{l} \mathrm{AC}$ with 2.4 roots per shoot and $2.5 \mathrm{~cm}$ root length. Plantlets were then transferred to ex vitro condition for acclimatization on a mixture of burned-rice husk and organic manure $(1: 1, \mathrm{v} / \mathrm{v})$ with $85-100 \%$ survivability. 'Black Jack' and 11.46 clone were the best genotypes with $100 \%$ survivability.

\section{References}

Akter N, Hoque MI, Sarker RH (2012). In vitro propagation in three varieties of gerbera (Gerbera jamesonii Bolus) from flower bud and flower stalk explants. Plant Tissue Culture and Biotechnology 22(2):143-152.

Arias AMG, Valverde JM, Fonseca PR, Melara MV (2010). In vitro plant regeneration system for common bean (Phaseolus vulgaris): effect of N6benzylaminopurine and adenine sulphate. Electronic Journal of Biotechnology 13(1):1-8.

Aswath CR, Choudhary ML (2002). Rapid plant regeneration from Gerbera jamesonii Bolus callus cultures. Acta Botanica Croatica 61(2):125-134.

Awal A, Ahmed ABA, Taha RM, Yaacob JS, Mohajer S (2013). Effect of adenine, sucrose and plant growth regulators on the indirect organogenesis and on in vitro flowering in Begonia $\mathrm{x}$ hiemalis Fotsch. Australian Journal of Crop Science 7(5):691-698.

Bantawa P, Roy OS, Ghosh P, Mondal TK (2009). Effect of bavistin and adenine sulphate on In vitro shoot multiplication of Picrorhiza scrophulariiflora Pennell: an endangered medicinal plant of Indo-China Himalayan Regions. Plant Tissue Culture and Biotechnology 19(2):237-245.

Bhargava B,Dilta BS, Gupta YC,Dhiman SR, Modgil M(2013). Studies on micropropagation of gerbera (Gerbera jamesonii Bolus). Indian Journal of Applied Research 3(11):8-11.

Bui VL, Hang Phuong NT, Anh Hong LT, Tran Thanh Van K (1999). High frequency shoots regeneration from Rhynchostylis gigantea (Orchidaceae) using thin cell layer. Plant Growth Regulation 28:179185.

Cardoso JC, Teixeira da Silva JA (2013). Gerbera micropropagation. Biotechnology Advances 31:1344-1357.

CBI (2016). CBI Trade Statistics: Cut Flower and Foliage. www.cbi.eu/market-information pp: 1-9.

Dahab, TAMA (2006). In vitro propagation of Hydrangea macrophylla Thunb', Arabian Journal of Biotechnology 10(1):161-178.

Deepika R, Kanwar K (2010). In vitro regeneration of Punica granatum L. plants from different juvenile explants. Journal of Fruit and Ornamental Plant Research 18(1):5-22.

Gabriela V (2011). Effect of adenine sulfate $\left(\mathrm{AdSO}_{4}\right)$ on the in vitro evolution of white clover variety (Trifolium repens L.). Analele Universitatii din Oradea, Fascicula Protectia Mediului 17:203-210.

Gantait S, Mandall N, Das PK (2009). Impact of auxins and activated charcoal on in vitro rooting of Dendrobium chrysotoxum Lindl. cv. Golden Boy.Journal of Tropical Agriculture 47(1-2):84-86.

Gök KM, Şan B, Bayhan AK (2016). Micropropagation of Gerbera (Gerbera jamesonii Bolus) under different color of light-Emitting diodes. Journal of Natural and Applied Sciences 20(3):468-474.

Khan MK, Misra P, Sharma T, Shukla PK, Ramteke PW (2014). Effect of adenine sulfate on in vitro mass propagation of Stevia rebudiana Bertoni. Journal of Medicinal and Plant Research 8(13):543-549.

Khatun MM, Khatun H, Khanam D, Al-Amin MD (2010). In vitro root formation and plantlet development in Dendrobium orchid'. Bangladesh Journal of Agriculture Research 35(2):257-265.

Kanwar JK, Kumar S (2008). In vitro propagation of Gerbera - A review'. Horticulture Science (Prague) 35(1):35-44.

Kshirsagar K, Braganz, VJ (2012). Micropropagation of Rosa damascena Mill. through transverse thin cell layer culture. South Asian Journal of Experimental Botany 2(4):184189.

Kumar S, Kunwar JK (2006). Regeneration ability of petiole, leaf and petal 
explants in gerbera cut flower cultures in vitro. Folia Horticulturae Annual 18(2):57-64.

Kumar S, Kunwar JK (2007). Plant regeneration from cell suspensions in Gerbera jamesonii Bolus. Journal of Fruit and Ornamental Plant Research 15:157-166.

Le BV, Nhut DT, Tran Thanh Van K (1999). Plant production via shoot regeneration from thin cell layer pseudo-bulblet explants of Lilium longiflorum in vitro. Comptes Rendus del'Academie des Sciences-Series III-Sciences dela Vie 322(4):303-310.

Mathur A, Mathur AK, Verma P, Yadav S, Gupta ML, Darokar MP (2008). Biological hardening and genetic fidelity testing of micro-cloned progeny of Chlorophytum borivilianum Sant. et Fernand. African Journal of Biotechnology 7(8):1046-1053.

Murthy KSR, Kondamudi R (2011). Rapid shoot regeneration from thin cell layer explants of an endangered medicinal asclepiad Ceropegia spiralis L.'Plant Tissue Culture and Biotechnology 21(1):63-73.

Mohamed SA, Özzambak ME (2014). Shoot regeneration capacity of in vitro cultures of some Gerbera (Gerbera jamesonii Bolus) explants. Sudanese Journal of Agriculture Sciences 1:2429.

Nandagopal S, Kumari BDR (2006). Adenine sulfate induced high frequency shoot organogenesis in callus and in vitro flowering of Cichorium intybus L. cv. Focus- apotent medicinal plant. Acta AgricultureSlovakia 87(2):415-425.

Naz S, Naz F, Tariq A, Aslam F, Ali A, Athar M (2012). Effect of different explants on in vitro propagation of gerbera (Gerbera jamesonii). African Journal Biotechnology 11(37):9048-9053.

Nhut DT, Hai NT, Huyen PX, Huong DTQ, Hang NTT (2005). Thidiazuron induces high frequency shoot bud formation from Begonia transverse thin cell layer culture. Propagagation of Ornamental Plants 5:151-157.

Nhut DT, Ana TTT, Huonga NTD, Dona NT, Haia NT, ... Vua NH (2007).Effect of genotype, explant size, position, and culture medium on shoot generation of Gerbera jamesonii by receptacle transverse thin cell layerculture. Scientia Horticulturae 111(2):146-151.

Nhut DT, Hai NT, Phan MX (2010). A highly efficient protocol for micropropagation of Begonia tuberous. In: Jain SM, Ochatt SJ (Eds.). Protocols for In vitro Propagation of Ornamental Plants, Springer protocols, Humana Press, pp 15-20.

Noiton D, Vine JH, Mullins MG (1992). Effects of serial subculture in vitro on the endogenous levels of indole-3-acetic acid and abscisic acid and rootability in microcuttings of 'Jonathan' apple. Plant Growth Regulation 11:377-383.

Saha M, Phatak A, Chandra N (2004). In vitro culture studies in four dioecious varieties of Carica papaya $\mathrm{L}$. using axillary buds from fieldgrown plants. Journal of Cell and Tissue Research 4(2):211-214.

Schmildt O, Schmildt ER, Amaral JAT (2007). Sulfato de adenina na multiplicação in vitro de mamoeiro "Tainung 01". Scientia Agraria 8(2):141-147.

Shabanpour K, Sharifi A, Bagheri A, Moshtaghi N (2011). Effect of genotypes and culture medium on shoot regeneration and proliferation of Gerbera jamesonii. African Journal of Biotechnology 10(57):1221112217
Shabbir K, Ahmad T, Hafiz IA, Hussain A, Abbasi NA, AhmadJ (2012). In vitro regeneration of Gerbera jamesonii cv. Sunglow. African Journal of Biotechnology 11(42):9975-9984.

Sharma T, Modgil M, Thakur M (2007). Factors affecting induction and development of in vitro rooting in apple rootstocks. Indian Journal of Experiment Biology 45:824829.

Shylaja MR, Sashna P, Chinjusha V, Nazeem PA (2014). An efficient microprogation protocol for Gerbera jamesonii Bolus from flower buds. International Journal of Plant, Animal and Environmental Sciences 4(3):641-643.

Son NV, Mokashi AN, Hegde RV, Patil VS, Lingaraju S (2011). Response of gerbera (Gerbera jamesonii Bolus) varieties to micropropagation. Karnataka Journal of Agriculture Science 24(3):354-357.

Stefaniak B (1994). Somatic embryogenesis and plant regeneration of Gladiolus (Gladiolus hort). Plant Cell Reports 13:386-389.

Teixeira da Silva JA (2003a). Thin cell layer technology in ornamental plant micropropagation and biotechnology. African Journal of Biotechnology 2(12):683-691.

Teixeira da Silva JA (2003b). Thin cell layer technology for induced response and control of rhizogenesis in chrysanthemum. Plant Growth Regulation 39:67-76.

Teixeira da Silva JA (2004). The effect of carbon source on in vitro organogenesis of chrysanthemum thin cell layers. Bragantia, Campinas 63(2):165-177.

Teixeira da Silva JA, Van KTT, BiondiS, NhutDT, Altamura MM(2006). Thin cell layers: developmental building blocks in ornamental biotechnology. FOB 1(1):1-13.

Teixeira da Silva JA, Fukai S (2003). Chrysanthemum organogenesis through thin cell layer technology and plant growth regulator control. Asian Journal of Plant Science 2:505-514

Teixeira da Silva JA (2008). Plant thin cell layers: challenging the concept. International Journal of Plant Development Biology 2(1):79-81.

Tran Thanh Van K (1980). Control of morphogenesis by inherent and exogenously applied factors in thin cell layers. International Review of Cytology 32:291-311.

Tyagi P, Kothari SL (2004). Rapid in vitro regeneration of Gerberajamesonii (H. Bolus ex Hook. f.) from different explants. Indian Journal of Biotechnology 3:584588.

Winarto B (2012). In vitro proliferation study of three Indonesian Dendrobiums protocorm-like bodies (plbs) on different fertilizer media. Prosiding Seminar Nasional Anggrek 2012, Jln. H. Adam Malik, No. 5, Medan, Sumatra Utara, 21 Juni 2012, pp 154169.

Winarto B, Setyawati AS (2014). Young shoot nodes derived organogenesis in vitro in mass propagation of Ruscus hypophyllum L. South Western Journal of Horticulture, Biology and Environment 5(2):63-82.

Wróblewska K (2012). The influence of adenine and benzyladenine on rooting and development of Fuchsia hybrida cuttings. Acta Agrobotanica 65(4):101-108.

Van Staden J, Zazimalova E, George EF (2008). Plant growth regulators II: Cytokinins, their analogues and antagonist. In: George EF, Hall M, De Kleck G.J. (Eds.) Plant Propagation by Tissue Culture. Vol. 1, The Background, Springer, The Netherlands, pp 205-226. 
76

Vardja R, Vardja T (2001). The effect of cytokinin type and concentration and the number of subcultures on the multiplication rate of some decorative plants. Proceeding of Estonian Academy of Science Biology and Ecology 50 (1):22-32.

Vujovic T, Ruzic Dj, Cerovic R (2012). In vitro shoot multiplication as influenced by repeated subculturing of shoots of contemporary fruit rootstocks. Horticulture Science (Prague) 39(3):101-107.

Vyas S, Guha S, Kapoor P, Rao IU (2010). Micropropagation of Cymbidium Sleeping Nymph through protocorm-like body production by thin cell layer culture. Scientia Horticultuare 123:551557.
Zhao P, Wang W, Feng FS, Wu F, Yang QZ, Wang WJ (2007). Highfrequency shoot regeneration through transverse thin cell layer culture in Dendrobium candidum Wall Ex Lindl. Plant Cell Tissue and Organ Culture 90:131-139.

Zibbu G, Batra A (2010). Effect of adenine sulfate on organogenesis via leat culture in an ornamental plant: Thevetia perwiana (Pers,) Schum. International Journal of Pharmacy and Bioscience 1(2):1-9. 